\title{
Rootstock-induced Differences in Flower Bud Phenology in Peach
}

\author{
Edward F. Durner and Joseph C. Goffreda \\ Rutgers Fruit Research Center, New Jersey Agricultural Experiment Station, Department of \\ Horticulture, Cook College, Rutgers University, R.D. 2, Box 38, Cream Ridge, NJ 08514
}

Additional index words. bloom delay, production efficiency, cold hardiness, Prunus persica

\begin{abstract}
Three peach [Prunus persica (L.) Batsch] rootstock plantings were monitored for date and rate of bloom during Spring 1989 and 1990 to determine if the time of scion bloom on different rootstocks is determined by the date of initiation of bud growth in the spring or by the duration of a particular bud stage. Included were a 1984 planting of 'Redhaven' on eight rootstocks, a 1984 planting of 'Rio-Oso-Gem' and 'Loring', each on 11 rootstocks, and a 1986 planting of 'Encore' on 18 rootstocks. The effect of rootstock on bud phenology was consistent within scion cultivar over two extremely different spring temperature profiles. In 'Redhaven' and 'Rio-Oso-Gem', rootstocks affected the dates but not the rates of bud development. Rootstocks affected both the dates and rates of 'Loring' and 'Encore' bud development. No consistent effect of rootstock on yield could be associated with delayed bud development in 'Rio-Oso-Gem', 'Redhaven', or 'Loring'; however, delayed bud development of 'Encore' on 'Okinawa' $x$ 'Cardinal' and 62325 resulted in enhanced yield following spring frosts.
\end{abstract}

Peach pistils are often killed by frosts during bloom, and economic losses can occur if fruit yield is significantly reduced. Dormant peach flower buds avoid freezing injury by supercooling (Quamme, 1978), and the ability to supercool decreases in early spring as buds develop. Just before bloom, buds will tolerate low temperatures through extracellular freezing (Andrews et al., 1983), but when flowers are fully open, any freeze is likely to kill many pistils. Delaying bloom could reduce the losses by delaying the transition of flower buds from the frosttolerant to the frost-sensitive stage. Additionally, the probability of a frost decreases over time; thus, the later trees bloom, the less likely they are to be injured by frost. Bloom can be delayed by decreasing post-rest heat unit accumulation with overhead misting (Bauer et al., 1976), or whole tree whitewashing (Durner and Gianfagna, 1992; Whitten, 1897), or by increasing the chilling required for budbreak with the growth regulator ethephon (Durner and Gianfagna, 1990). Overhead irrigation and whitewashing are expensive, and ethephon is not labeled for use on peach in the United States. Another alternative for delaying bloom is with rootstocks (Okie, 1990; Young and Houser, 1980; Young and Olcott-Reid, 1979). Since the transition of flower buds from a freeze-tolerant to a freeze-sensitive stage is gradual (Andrews et al., 1983), subtle differences in the rate of bloom development induced by rootstock could have significant consequences on pistil survival if a frost were to occur during the time when these differences were most prevalent.

The purposes of this study were to: 1) determine if the time of scion bloom on various rootstocks in peach is determined by the time of initiation of bud growth in the spring or by the duration of a particular bud stage, 2) characterize the time of bloom and the rate of bud development on different rootstocks in several rootstock plantings, and 3) determine if any observed differences in bud development alter yield, harvest date, or fruit size.

Received for publication 29 Aug. 1991. Accepted for publication 18 Feb. 1992. New Jersey Agricultural Experiment Station, Publication no. D-12220-22-91, supported by state and Hatch Act funds. The cost of publishing this paper was defrayed in part by the payment of page charges. Under postal regulations, this paper therefore must be hereby marked advertisement solely to indicate this fact.

\section{Materials and Methods}

Three rootstock plantings at Rutgers Fruit Research Center in Cream Ridge, N.J. were monitored for bloom development during Spring 1989 and 1990. The plantings included: 1) a 1984 planting of 'Redhaven' on its own roots or budded to the seedling rootstocks 'Bailey', 'Siberian C', 'Lovell', or 'Halford' or the clonal rootstocks GF 655.2, GF 677 ('Amandier'), or 'Damas' (GF 1869); 2) a 1984 planting of 'Rio-Oso-Gem' and 'Loring' on their own roots or budded to seedling rootstocks of 'Tzim Pee Tao', six Harrow selections (H) H7141041, H7141049, H7338013, H7141064, H7338001, H7141137, Lovell, Halford, Citation, or Sinung Chui; 'Loring' was also budded to 'Chui Lum Tao' and 'Bailey' seedlings; and 3) a 1986 planting of 'Encore' on seedling 'Lovell' rootstocks, and semi-hardwood cuttings of 'Lovell', 'Nemaguard', 'Okinawa' x 'Cardinal', 'Honeyglo', 62325, B81150，B813121，B820171，B89298, C22889, C25165, RR53117, RR5345, RR5354, RR62196, RR63190, and RR70288. The 'Redhaven' and 'Encore' blocks were planted in separate randomized complete blocks with rootstock as the treatment, and the 'Rio-Oso-Gem'/'Loring' block was split-plot with cultivar as the main plot and rootstock as the subplot. The three plantings were adjacent on a well-drained sandy loam with a mean $\mathrm{pH}$ of 6.2. Tree spacing was $4.6 \mathrm{x}$ $6.1 \mathrm{~m}$ in rows oriented east-west with a slight westerly slope $\left(<5^{\circ}\right)$. Trees were dormant-pruned to an open center and maintained at a maximum tree height of $2 \mathrm{~m}$. Two terminal shoots on each of six to 10 trees of each cultivar/rootstock combination were observed beginning when flower bud scales began to separate, indicating bud swell [27 Mar. 1989 (Julian date 86) and 19 Mar. 1990 (Julian date 77)]. Observations were made every several days thereafter until all blossoms were fully open. The number of quiescent, pink, balloon, and fully open buds was recorded. Bud development rates were defined as the number, of days a majority of buds on a tree remained in each stage. This value was calculated as the number of days it took to decrease the proportion of buds in the quiescent stage from $75 \%$ to $25 \%$, and to increase the proportion of buds in the pink, balloon, or full bloom stages from $25 \%$ to $75 \%$. The dates of bud development were calculated as the Julian dates on which $75 \%$ of the buds were at the pink, balloon, or fully open stage. All values were calculated for individual trees. The data over years were combined and an analysis of variance (ANOVA) for experiments repeated over time (Gomez and Gomez, 1984) was 
performed on data using the general linear models procedure of SAS (SAS Institute, Cary, N.C.). The 'Redhaven' and 'Encore' plantings were analyzed separately, by use of a randomized complete-block model for each. The 'Rio/Loring' planting was analyzed using a split-plot model. A significant interaction between rootstock and scion cultivar was detected for all dependent variables in this planting, thus each scion cultivar was reanalyzed using a randomized complete-block model. Year main effects were separated with Fisher's protected LSD, $\alpha=0.05$, and rootstock main effect means were separated with the RyanEinot-Gabriel-Welsch Multiple F test of SAS, $01=0.05$. Chilling units and growing degrees hours (GDH) were calculated according to the methods of Richardson et al. (1974, 1975). GDH accumulation began on 1 Jan. 1989 and 30 Jan. 1990 (Fig. 2).

Fruit were thinned by hand to 15 to $20 \mathrm{~cm}$ apart, if needed. Firm, well-colored 'Redhaven' fruit were hand-harvested on 21, 25, 28, and 31 July and 7 Aug. 1989; and on 27 July and 2 Aug. 1990. 'Loring' fruit were harvested on 8, 10, and 14 Aug. 1989 and on 6 and 13 Aug. 1990. 'Rio Oso Gem' fruit were harvested on 23 Aug. 1989 and 28 Aug. 1990. 'Encore' fruit were harvested on 28 Aug. and 15 Sept. 1989, and 23 and 28 Aug. 1990. Fruit $<6.4 \mathrm{~cm}$ in diameter were discarded. When more than two harvests were performed for a cultivar, data were combined to provide two harvest dates (early and late) within cultivar and year to simplify data analysis and interpretation. Average fruit size was calculated as the total weight of fruit harvested divided by the total number of fruit harvested. Weight and average size of marketable fruit and percent of the total harvest on a per-tree basis were analyzed by ANOVA, using a split-block model (Steel and Torrie, 1980) for experiments repeated over time (Gomez and Gomez, 1984) for all but the 'RioOso-Gem' data, which were analyzed using a randomized complete-block model. Rootstock was the main block and harvest date was the subblock. The split-block model is a modification of the split-plot model that computes a greater number of error terms for hypothesis testing to compensate for the fact that harvest date cannot be randomly assigned. Each scion cultivar was analyzed separately. Tree vigor was estimated by calculating the trunk cross-sectional area $30 \mathrm{~cm}$ above the bud union in June. Production efficiency was estimated by dividing yield per tree by the trunk cross-sectional area $30 \mathrm{~cm}$ above the bud union (Lombard et al., 1988). Tree vigor and production efficiency data were analyzed with an ANOVA based on a randomized complete-block model over years (Gomez and Gomez, 1984). Rootstock main effects were separated using the Ryan-EinotGabriel-Welsch test at $\alpha=0.05$. All other means were separated using Fisher's protected LSD at $\alpha=0.05$.

\section{Results}

\section{'Redhaven'}

Dates of bud development. Rootstock significantly affected the mean date of development to the $75 \%$ pink and balloon stages (Table 1). Buds on Damas GF 1869 and GF 677 were $75 \%$ pink 2.3 days earlier and $75 \%$ balloon 5.2 days earlier than buds on 'Halford', 'Siberian C', or self-rooted trees. Buds on Damas GF 1869 were $75 \%$ pink 1.2 days earlier and $75 \%$ balloon 3.9 days earlier than buds on 'Bailey' and 'Lovell'. Bud development was earlier in 1990 than in 1989. The mean Julian dates for $75 \%$ pink, $75 \%$ balloon, and $75 \%$ fully open buds were 97.5, 101.3, and 105.6, respectively, in 1989, and 83.0,
Table 1. Flower bud development of 'Redhaven' peach as affected by eight rootstocks during 1989 and 1990 .

\begin{tabular}{lll}
\hline & \multicolumn{2}{c}{ Julian date of $75 \%$ buds in each stage } \\
\cline { 2 - 3 } Rootstock & \multicolumn{1}{c}{ Pink } & Balloon \\
\hline Self-rooted & $90.9 \mathrm{abc}^{\mathbf{2}}$ & $98.9 \mathrm{a}$ \\
Bailey & $90.2 \mathrm{abc}$ & $97.6 \mathrm{ab}$ \\
Siberian C & $91.5 \mathrm{ab}$ & $99.6 \mathrm{a}$ \\
Lovell & $91.0 \mathrm{ab}$ & $97.6 \mathrm{ab}$ \\
Halford & $91.9 \mathrm{a}$ & $99.1 \mathrm{a}$ \\
GF 655.2 & $90.3 \mathrm{abc}$ & $96.7 \mathrm{abc}$ \\
GF 677 & $88.8 \mathrm{c}$ & $94.3 \mathrm{bc}$ \\
Damas GF 1869 & $89.4 \mathrm{bc}$ & $\cong 3.7 \mathrm{c}$
\end{tabular}

${ }^{1}$ Mean separation of rootstocks within column by Ryan-Einot-GabrielWelsh multiple $F$ test, $\alpha=0.05$, means of five observations per rootstock per year.

Table 2. Mean yield per tree, percentage of total crop harvested early, fruit number per tree, production efficiency, and tree vigor for 'Redhaven' peach in 1989 and 1990 as affected by rootstock.

\begin{tabular}{|c|c|c|c|c|c|}
\hline \multirow[b]{2}{*}{ Rootstock } & \multicolumn{2}{|c|}{ Mean yield/tree } & \multirow[b]{2}{*}{$\begin{array}{l}\text { Total crop } \\
\text { harvested } \\
\text { early }(\%)\end{array}$} & \multirow[b]{2}{*}{$\begin{array}{l}\text { Production } \\
\text { efficiency } \\
\left(\mathrm{kg} \cdot \mathrm{cm}^{-2}\right)\end{array}$} & \multirow[b]{2}{*}{$\begin{array}{c}\text { Tree } \\
\text { vigor } \\
\mathrm{m}^{2} \text { TCSA }^{2} \text { ) }\end{array}$} \\
\hline & $\begin{array}{c}\text { Wt } \\
(\mathrm{kg})\end{array}$ & $\begin{array}{l}\text { Fruit } \\
\text { count } \\
\text { (no.) } \\
\end{array}$ & & & \\
\hline & \multicolumn{5}{|c|}{1989} \\
\hline Self-rooted & $45.1 \mathrm{a}^{\mathrm{y}}$ & $257 \mathrm{ab}$ & $67 a$ & 0.46 & $99 \mathrm{bcd}$ \\
\hline Bailey & $40.0 \mathrm{ab}$ & $255 \mathrm{ab}$ & $62 \mathrm{ab}$ & 0.36 & $111 a b$ \\
\hline Siberian $\mathrm{C}$ & $43.9 \mathrm{ab}$ & $237 \mathrm{ab}$ & $46 \mathrm{ab}$ & 0.42 & $107 \mathrm{abc}$ \\
\hline Lovell & $51.7 \mathrm{a}$ & $292 \mathrm{a}$ & $23 \mathrm{~b}$ & 0.51 & $100 \mathrm{a}-\mathrm{d}$ \\
\hline Halford & $43.2 \mathrm{ab}$ & $275 a b$ & $49 \mathrm{ab}$ & 0.39 & $113 \mathrm{ab}$ \\
\hline GF 655.2 & $26.4 \mathrm{~b}$ & $154 \mathrm{~b}$ & $64 a$ & 0.31 & $84 \mathrm{~cd}$ \\
\hline GF 677 & $42.8 \mathrm{ab}$ & $237 a b$ & $46 a b$ & 0.35 & $124 \mathrm{a}$ \\
\hline \multirow[t]{2}{*}{ Damas GF 1869} & $31.9 \mathrm{ab}$ & $216 \mathrm{ab}$ & $32 a b$ & 0.39 & $84 \mathrm{~d}$ \\
\hline & \multicolumn{5}{|c|}{1990} \\
\hline Self-rooted & $22.3 \mathrm{a}$ & $156 \mathrm{ab}$ & $75 \mathrm{a}$ & $0.19 \mathrm{a}$ & $118 b c$ \\
\hline Bailey & $24.2 \mathrm{a}$ & $173 a$ & $64 a b$ & $0.19 \mathrm{a}$ & $144 \mathrm{ab}$ \\
\hline Siberian C & 28.9 a & $225 \mathrm{a}$ & $26 \mathrm{c}$ & $0.28 \mathrm{a}$ & $118 b c$ \\
\hline Lovell & $35.7 \mathrm{a}$ & $254 a$ & $29 \mathrm{bc}$ & $0.31 \mathrm{a}$ & $117 \mathrm{c}$ \\
\hline Halford & $26.4 \mathrm{a}$ & $195 \mathrm{a}$ & $54 \mathrm{abc}$ & $0.19 \mathrm{a}$ & $137 \mathrm{abc}$ \\
\hline GF 655.2 & $3.3 \mathrm{~b}$ & $25 \mathrm{c}$ & $72 \mathrm{a}$ & $0.04 b$ & $110 \mathrm{c}$ \\
\hline GF 677 & $24.9 \mathrm{a}$ & $200 a$ & $42 a b c$ & $0.19 \mathrm{a}$ & $150 \mathrm{a}$ \\
\hline Damas GF 1869 & $6.1 \mathrm{~b}$ & $44 \mathrm{bc}$ & $72 \mathrm{a}$ & $0.02 \mathrm{~b}$ & $104 \mathrm{c}$ \\
\hline
\end{tabular}

${ }^{\mathrm{a}}$ Trunk cross-sectional area.

'Mean separation of rootstocks within column by Ryan-Einot-GabrielWelsh multiple $F$ test, $\alpha=0.05$; means of a minimum of seven samples.

93.0, and 99.5, respectively, in 1990. No rootstock $\times$ year interaction was observed for development to any stage.

Bud development rates. Rootstock did not affect the rate of bud development in either year, and no rootstock $\times$ year interaction was detected. Time in each stage averaged 4.8 days for quiescent, 4.8 for pink, 7.6 for balloon, and 6.5 for fully open buds. No effect of year on the length of the quiescent or pink stage was observed; however, buds were balloon and fully open longer in 1990 (an average of 10.2 days balloon and 7.9 days fully open) than in 1989 (an average of 5.3 days balloon and 5.2 days fully open).

Yield components. In 1989, trees on GF 655.2 had lower yields than self-rooted trees or trees on 'Lovell', and in 1990, trees on GF 655.2 and Damas GF 1869 had lower yields than trees on any other rootstock (Table 2). In both years, self-rooted trees and trees on GF 655.2 were harvested earlier than trees on 'Lovell'. In 1990, trees on Damas GF 1869 were harvested 
earlier than trees on 'Siberian C' and 'Lovell', and trees on 'Bailey' were harvested earlier than trees on 'Siberian C'. In 1989, GF 655.2 carried fewer fruit than 'Lovell'. In 1990, trees on Damas GF 1869 and GF 655.2 carried fewer fruit than trees on 'Lovell', 'Siberian C', GF 677, 'Halford', and 'Bailey'. Self-rooted trees carried more fruit than GF 655.2. No rootstock influence on production efficiency was detected in 1989; however, in 1990, trees on GF 655.2 and Damas GF 1869 were less efficient than those on any other rootstock.

In both years, the most vigorous trees were on GF 677 and the least vigorous were on Damas GF 1869, although differences between them and some other rootstocks were not significant. Vigor of trees on all other rootstocks was intermediate (Table 2). Average fruit size was not significantly affected by rootstock in either year, but was significantly higher in 1989 (168 g/fruit) than in 1990 (145 g/fruit), even though the crop load was lighter in 1990 (an average of 240 fruit per tree in 1989 and 159 fruit per tree in 1990).

\section{'Loring'}

Dates of bud development. Rootstock significantly affected bud development to the pink, balloon, and fully open stages (Table 3). Buds on 'Tzim Pee Tao' and 'Citation' were 75\% pink 2.5 days later than buds on 'Bailey', 'Lovell', 'Sinung Chui', H7141137, H7141064, H7338001, and H7338013, and buds on $\mathrm{H} 7141049$ were $75 \%$ pink 2.1 days later than those on H7338013. Buds on 'Tzim Pee Tao' were $75 \%$ balloon 5.3 days later than those on 'Bailey', 'Lovell', 'Sinung Chui', 'Chui Lum Tao', H7141041, H7141137, H7141064, H7338013, and H7338001, and buds on 'Citation' were $75 \%$ balloon 5.6 days later than those on 'Lovell', 'Sinung Chui', 'Chui Lum Tao', H7141064, H7338013, and H7338001. Buds on 'Citation' were $75 \%$ fully open 6 days later than buds on 'Sinung Chui' and 'Chui Lum Tao'. A significant effect of year was detected, but no rootstock $\times$ year interaction was detected; thus, the data for 1989 and 1990 were averaged (Table 3). Bud development was earlier in 1990 (Julian dates of 77.0, 89.6, and 99.7 for pink, balloon, and fully open, respectively) than in 1989 (Julian dates of 90.5, 97.7, and 105.0 for pink, balloon, and fully open, respectively).

Bud development rates. Rootstock significantly affected the

Table 3. Flower bud development of 'Loring' peach during 1989 and 1990 as affected by rootstock.

\begin{tabular}{|c|c|c|c|c|c|}
\hline \multirow[b]{2}{*}{ Rootstock } & \multicolumn{3}{|c|}{$\begin{array}{l}\text { Julian date of } 75 \% \text { buds } \\
\text { in each stage }\end{array}$} & \multicolumn{2}{|c|}{$\begin{array}{l}\text { Days in each } \\
\text { bud stage }\end{array}$} \\
\hline & Pink & Balloon & Full & Quiescent & Pink \\
\hline Lovell & $82.6 \mathrm{~cd}^{\mathrm{z}}$ & $91.6 \mathrm{c}$ & $101.5 \mathrm{ab}$ & $3.2 \mathrm{c}$ & $3.2 \mathrm{c}$ \\
\hline Self-rooted & $84.0 \mathrm{a}-\mathrm{d}$ & $94.8 \mathrm{abc}$ & $103.5 \mathrm{ab}$ & $4.9 \mathrm{a}$ & $5.0 \mathrm{a}$ \\
\hline Citation & $85.5 \mathrm{a}$ & $97.5 \mathrm{ab}$ & $106.0 \mathrm{a}$ & $4.5 \mathrm{ab}$ & $4.7 \mathrm{abc}$ \\
\hline Tzim Pee Tao & $85.5 \mathrm{a}$ & $97.8 \mathrm{a}$ & $105.2 \mathrm{ab}$ & $4.3 \mathrm{ab}$ & $4.9 \mathrm{ab}$ \\
\hline Sinung Chui & $83.1 \mathrm{~cd}$ & $91.6 \mathrm{c}$ & $100.6 \mathrm{~b}$ & $3.4 \mathrm{bc}$ & $3.5 c$ \\
\hline Chui Lum Tao & $83.7 \mathrm{a}-\mathrm{d}$ & $90.8 \mathrm{c}$ & $99.5 \mathrm{~b}$ & $3.4 \mathrm{bc}$ & $3.8 \mathrm{abc}$ \\
\hline Bailey & $83.6 \mathrm{bcd}$ & $93.2 \mathrm{bc}$ & $102.5 \mathrm{ab}$ & $3.8 \mathrm{bc}$ & $4.1 a b c$ \\
\hline H7141041 & $84.2 \mathrm{a}-\mathrm{d}$ & 93.7 bc & $101.0 \mathrm{ab}$ & $4.0 \mathrm{abc}$ & $4.0 \mathrm{abc}$ \\
\hline H7141137 & $83.3 \mathrm{bcd}$ & $93.6 \mathrm{bc}$ & $102.6 a b$ & $3.6 \mathrm{bc}$ & $3.5 \mathrm{c}$ \\
\hline H7338013 & $82.4 \mathrm{~d}$ & $92.3 c$ & $102.7 \mathrm{ab}$ & $3.6 \mathrm{bc}$ & $3.7 \mathrm{bc}$ \\
\hline H7338001 & $83.2 \mathrm{~cd}$ & $92.8 \mathrm{c}$ & $102.6 \mathrm{ab}$ & $3.4 \mathrm{bc}$ & $3.6 \mathrm{bc}$ \\
\hline H7141049 & $84.5 \mathrm{abc}$ & $94.5 \mathrm{abc}$ & $101.4 \mathrm{ab}$ & $3.3 \mathrm{c}$ & $3.7 \mathrm{bc}$ \\
\hline H7141064 & $82.6 \mathrm{~cd}$ & $92.6 \mathrm{c}$ & $101.8 \mathrm{ab}$ & $3.3 \mathrm{c}$ & $3.2 \mathrm{c}$ \\
\hline
\end{tabular}

${ }^{2}$ Mean separation of rootstocks within column by Ryan-Einot-GabrielWelsh multiple $F$ test, $\alpha=0.05$; means of eight to 12 observations per rootstock each year, both years combined. duration of the quiescent and pink stages (Table 3). Buds on self-rooted trees were quiescent 1.5 days longer than buds on H7338001, H7338013, H7141137, H7141049, H7141064, 'Bailey', 'Chui Lum Tao', 'Sinung Chui', and 'Lovell'. Buds on 'Tzim Pee Tao' and 'Citation' were quiescent 1.1 days longer than buds on 'Lovell', H7141049, and H7141064. Buds on selfrooted trees were pink 1.5 days longer than those on 'Lovell', 'Sinung Chui', H7141137, H7141064, H7338013, H7338001, and H7141049, while buds on 'Tzim Pee Tao' were pink 1.6 days longer than buds on 'Lovell', 'Sinung Chui', H7141137, and H7141064. No differences among rootstocks were detected for the balloon (8.5 days) or fully open (9.3 days) stages and no rootstock $\times$ year interaction was detected for any stage. A significant influence of year was observed. Buds on all rootstocks were quiescent and pink longer in 1989 (4.0 and 4.2 days for quiescent and pink, respectively) than in 1990 (3.4 and 3.6 days for quiescent and pink, respectively), but buds were in the balloon and fully open stages for less time in 1989 (5.9 and 5.8 days for balloon and fully open, respectively) than in 1990 (11.1 and 12.7 days for balloon and fully open, respectively).

Yield components. In 1989, trees on H7141064 had a higher yield than those on 'Citation' (Table 4), but there was no effect of rootstock on yield in 1990 (mean yield per tree was $3.5 \mathrm{~kg}$ ). No effect of rootstock on harvest date was detected in either year. Average fruit size was larger in 1989 (236 g/fruit) than in 1990 (187 g/fruit). In 1989, trees on H7338001 carried more fruit than trees on 'Citation' (287 and 44 fruit per tree, respectively). The effect of all other rootstocks was intermediate and similar among each other, H7338001 or 'Citation'. In 1990, there was no rootstock effect on the number of fruit per tree (mean of 16 fruit per tree).

A significant rootstock effect on production efficiency was detected in 1989 (Table 4) but not in 1990 (mean production efficiency $=0.03 \mathrm{~kg} \cdot \mathrm{cm}^{2}$ ). In 1989 , trees on 'Tzim Pee Tao' were more efficient than trees on 'Citation' or 'Lovell', and trees on 'Lovell' or H7338001 were more efficient than trees on 'Citation'. In 1990, trees on 'Tzim Pee Tao' tended to be

Table 4. Mean yield per tree, production efficiency, and tree vigor of 'Loring' peach in 1989 and tree vigor in 1990 as affected by rootstock.

\begin{tabular}{|c|c|c|c|c|}
\hline \multirow[b]{2}{*}{ Rootstock } & \multicolumn{3}{|c|}{1989} & \multirow{2}{*}{$\begin{array}{c}1990 \\
\text { Tree } \\
\text { vigor } \\
\left(\mathrm{cm}^{2} \text { TCSA }\right)\end{array}$} \\
\hline & $\begin{array}{l}\text { Yield/tree } \\
(\mathrm{kg})\end{array}$ & $\begin{array}{l}\text { Production } \\
\text { efficiency } \\
\left(\mathrm{kg} \cdot \mathrm{cm}^{-2}\right)\end{array}$ & $\begin{array}{c}\text { Tree } \\
\text { vigor } \\
\left(\mathrm{cm}^{2} \mathrm{TCSA}^{\mathrm{z}}\right)\end{array}$ & \\
\hline Lovell & $30.4 a b^{y}$ & $0.24 \mathrm{bc}$ & $125 \mathrm{a}$ & $153 a$ \\
\hline Self-rooted & $---x$ & --- & $42 \mathrm{~b}$ & $63 c$ \\
\hline Citation & $9.0 \mathrm{~b}$ & $0.16 \mathrm{c}$ & $70 \mathrm{ab}$ & $77 \mathrm{bc}$ \\
\hline Tzim Pee Tao & $50.0 \mathrm{ab}$ & $0.73 \mathrm{a}$ & $75 \mathrm{ab}$ & $90 \mathrm{abc}$ \\
\hline Sinung Chui & $35.8 \mathrm{ab}$ & $0.29 \mathrm{abc}$ & $98 \mathrm{a}$ & $134 \mathrm{ab}$ \\
\hline Chui Lum Tao & $\cdots$ &.- &.- & -- \\
\hline Bailey & $40.1 \mathrm{ab}$ & $0.46 \mathrm{abc}$ & $93 \mathrm{ab}$ & $115 \mathrm{abc}$ \\
\hline H7141041 & $45.9 \mathrm{ab}$ & $0.44 \mathrm{abc}$ & $91 \mathrm{ab}$ & $120 \mathrm{ab}$ \\
\hline H7141137 & $31.8 \mathrm{ab}$ & $0.32 \mathrm{abc}$ & $105 a$ & $125 \mathrm{ab}$ \\
\hline H7338013 & $28.8 \mathrm{ab}$ & $0.30 \mathrm{abc}$ & $113 \mathrm{a}$ & $147 \mathrm{a}$ \\
\hline H7338001 & $55.2 \mathrm{ab}$ & $0.71 \mathrm{ab}$ & $83 a b$ & $106 \mathrm{abc}$ \\
\hline H7141049 & $44.8 \mathrm{ab}$ & $0.56 \mathrm{abc}$ & $97 \mathrm{ab}$ & $132 \mathrm{ab}$ \\
\hline $\mathrm{H} 7141064$ & $56.9 \mathrm{a}$ & $0.65 \mathrm{abc}$ & $94 \mathrm{ab}$ & $114 \mathrm{abc}$ \\
\hline
\end{tabular}

${ }^{2}$ Trunk cross-sectional area.

'Mean separation of rootstocks within column by Ryan-Einot-GabrielWelsh multiple $F$ test, $\alpha=0.05$. Data are means of a minimum of seven samples.

'Inadequate sample size to estimate production efficiency. 
the most efficient, but the differences among rootstocks were not statistically significant. Rootstock influenced tree vigor; 'Lovell', 'Sinung Chumi', H7141137, and H7338013 were more vigorous than self-rooted trees in 1989, and H7338013 and 'Lovell' were more vigorous than 'Citation' and self-rooted trees in 1990. H7141049 was also more vigorous than self-rooted trees in 1990.

\section{'Rio-Oso-Gem'}

Dates of bud development. Rootstock significantly affected bud development dates (Table 5). Buds on H7338013, H7141049, and $\mathrm{H} 7141064$ were $75 \%$ pink 3.7 days later than buds on 'Sinung Chui'; buds on H7338013, and H7141049 were $75 \%$ pink 3.0 days later than buds on 'Citation', and buds on H7338013 were $75 \%$ pink 2.7 days later than those on H7141041. Buds on 'Tzim Pee Tao', H7141137, H7141049, H7141064, H7338001, H7338013, or self-rooted trees were $75 \%$ balloon 3.9 days later than buds on 'Sinung Chui'. Buds on H7338013 or H7141064 were $75 \%$ fully open 2.6 days later than those on 'Sinung Chui' (Table 5). A significant influence of year on the date of bud development was observed and no interaction of year with rootstock was detected. Buds developed earlier in 1990 (Julian dates of 79.6, 92.8 and 100.2 for pink, balloon, and fully open, respectively) compared with 1989 (Julian dates of 95.0, 102.5, and 108.0 for pink, balloon, and fully open, respectively).

Bud development rates. There was no rootstock effect on the duration of the quiescent (mean 4.8 days), pink (4.8 days), balloon (8.1 days), or fully open stage (5.4 days). Buds were quiescent and pink 1 day longer in 1989 (5.3 days for both stages) than in 1990 (4.3 days for both stages); however, buds were balloon and fully open longer in 1990 (10.2 and 7.0 days, respectively) than in 1989 (5.8 and 3.7 days, respectively). No year $\times$ rootstock interaction was detected for any stage.

Yield components. In 1989, trees on 'Lovell' (mean yield $33.9 \mathrm{~kg} /$ tree), and 'Tzim Pee Tao' (mean yield $31.8 \mathrm{~kg} /$ tree) produced more fruit than trees on 'Citation' (mean yield 19.1 $\mathrm{kg} /$ tree), H7338001 (mean yield $16.1 \mathrm{~kg} /$ tree), or self-rooted trees (mean yield $14.9 \mathrm{~kg} /$ tree). All other rootstocks (mean yield $26.7 \mathrm{~kg} /$ tree) produced more fruit than self-rooted trees. In 1990 there was no rootstock effect on yield, and the mean yield per tree was $3.8 \mathrm{~kg}$. Average fruit size was $116 \mathrm{~g}$ in 1989 and 191 $\mathrm{g}$ in 1990 , and was not affected by rootstock in either year. The

Table 5. Flower bud development of 'Rio-Oso-Gem' peach as affected by 13 rootstocks during 1989 and 1990.

\begin{tabular}{llll}
\hline \hline & \multicolumn{3}{c}{ Julian date of $75 \%$ buds in each stage } \\
\cline { 2 - 4 } Rootstock & \multicolumn{1}{c}{ Pink } & Balloon & Full \\
\hline Lovell & $86.8 \mathrm{a}-\mathrm{d}^{\mathbf{z}}$ & $96.1 \mathrm{ab}$ & $103.0 \mathrm{ab}$ \\
Self-rooted & $87.4 \mathrm{a}-\mathrm{d}$ & $97.8 \mathrm{a}$ & $104.2 \mathrm{ab}$ \\
Citation & $85.8 \mathrm{~cd}$ & $97.0 \mathrm{ab}$ & $103.8 \mathrm{ab}$ \\
Tzim Pee Tao & $86.9 \mathrm{a}-\mathrm{d}$ & $97.4 \mathrm{a}$ & $104.7 \mathrm{ab}$ \\
Sinung Chumi & $84.8 \mathrm{~d}$ & $94.4 \mathrm{~b}$ & $102.4 \mathrm{~b}$ \\
H7141041 & $86.2 \mathrm{bcd}$ & $97.3 \mathrm{ab}$ & $103.9 \mathrm{ab}$ \\
H7141137 & $87.4 \mathrm{a}-\mathrm{d}$ & $98.3 \mathrm{a}$ & $103.8 \mathrm{ab}$ \\
H7338013 & $88.9 \mathrm{a}$ & $98.9 \mathrm{a}$ & $104.9 \mathrm{a}$ \\
H7338001 & $86.8 \mathrm{a}-\mathrm{d}$ & $98.2 \mathrm{a}$ & $103.9 \mathrm{ab}$ \\
H7141049 & $88.6 \mathrm{ab}$ & $98.2 \mathrm{a}$ & $104.4 \mathrm{ab}$ \\
H7141064 & $88.1 \mathrm{abc}$ & $99.1 \mathrm{a}$ & $105.1 \mathrm{a}$ \\
\hline
\end{tabular}

${ }^{7}$ Mean separation of rootstocks within column by Ryan-Einot-GabrielWelsh multiple $\mathrm{F}$ test, $\alpha=0.05$; means of five to 11 observations per rootstock each year. number of fruit per tree was not affected by rootstock in either year (231 fruit per tree in 1989 and 21 fruit per tree in 1990). Production efficiency was not affected by rootstock in either year $\left(0.35\right.$ and $0.04 \mathrm{~kg}$ fruit/ $\mathrm{cm}^{*}$ trunk cross-sectional area, for 1989 and 1990, respectively). Tree vigor was not affected by rootstock in either year (mean trunk cross-sectional area was 81 $\mathrm{cm}^{2}$ in 1989 and $93 \mathrm{~cm}^{2}$ in 1990).

\section{'Encore'}

Dates of bud development. Rootstock significantly affected bud development to the pink and fully open stages (Table 6). Buds on 62325 were $75 \%$ pink 2.6 days later than buds on B81150, C25165, RR53117, RR5345, RR5354, RR70288, or 'Lovell' cuttings, and buds on 'Okinawa' $\times$ 'Cardinal' were $75 \%$ pink 1.8 days later than buds on C25165, RR53117, RR5345, RR5354, RR70288 or 'Lovell' cuttings. All rootstocks were $75 \%$ balloon on a mean Julian date of 96.6. Buds on 'Nemaguard' or 62325 were $75 \%$ fully open 5.5 days later than on buds on RR5354 or RR70288 and 4.0 days later than buds on B81150, B820171，B89298，C22889，C25165，RR53117, RR5354, RR62196, RR63190, 'Honeyglo', 'Lovell' seedlings, or 'Lovell' cuttings. A significant influence of year on the date of bud development was observed. Buds were $75 \%$ pink and balloon earlier in 1990 (Julian dates of 82.4 and 95.0, respectively) than in 1989 (Julian dates of 94.0 and 98.3, respectively), but there was no difference between 1989 and 1990 in the date of $75 \%$ fully open flowers (Julian date 101). No interaction of year with rootstock was detected for any stage.

Bud development rates. There was no rootstock effect on the duration of the quiescent (4.9 days), pink (4.9 days), or fully open (8.0 days) stages; however, buds on C25165 were balloon 2.1 days longer than buds on 62325 or RR62196 (Table 6). Buds on all rootstocks were quiescent and pink longer in 1989 (5.3 and 5.4 days for each stage, respectively) compared to 1990 (4.4 days for both stages). Additionally, buds on all rootstocks were in the balloon and fully open stages for less time in 1989

Table 6. Flower bud development of 'Encore' peach as affected by 18 rootstocks during 1989 and 1990.

\begin{tabular}{|c|c|c|c|}
\hline \multirow[b]{2}{*}{ Rootstock } & \multirow{2}{*}{$\begin{array}{l}\text { Days in the } \\
\text { balloon stage }\end{array}$} & \multicolumn{2}{|c|}{$\begin{array}{c}\text { Julian date of } 75 \% \text { buds in } \\
\text { each stage }\end{array}$} \\
\hline & & Pink & Full \\
\hline 62325 & $6.8 b^{2}$ & $90.1 \mathrm{a}$ & $104.4 \mathrm{ab}$ \\
\hline $\mathrm{B} 81150$ & $7.5 \mathrm{ab}$ & $87.8 \mathrm{bc}$ & $100.2 \mathrm{bc}$ \\
\hline B813121 & $7.4 \mathrm{ab}$ & $88.7 \mathrm{abc}$ & $102.1 \mathrm{abc}$ \\
\hline B820171 & $7.8 \mathrm{ab}$ & $88.5 \mathrm{abc}$ & $101.1 \mathrm{bc}$ \\
\hline B89298 & $7.6 \mathrm{ab}$ & $88.8 \mathrm{abc}$ & $101.2 \mathrm{bc}$ \\
\hline $\mathrm{C} 22889$ & $7.3 \mathrm{ab}$ & 87.9 abc & $99.5 \mathrm{bc}$ \\
\hline $\mathrm{C} 25165$ & $8.9 \mathrm{a}$ & $87.4 \mathrm{bc}$ & $100.4 \mathrm{bc}$ \\
\hline Honeyglo & $7.8 \mathrm{ab}$ & $88.0 \mathrm{abc}$ & $101.0 \mathrm{bc}$ \\
\hline Lov. cut & $7.6 \mathrm{ab}$ & $87.2 \mathrm{bc}$ & $101.2 \mathrm{bc}$ \\
\hline Lov. sdlg & $7.3 \mathrm{ab}$ & $88.3 \mathrm{abc}$ & $100.7 \mathrm{bc}$ \\
\hline Nemaguard & $7.3 \mathrm{ab}$ & $88.9 \mathrm{abc}$ & $104.9 \mathrm{a}$ \\
\hline Okinawa $\times$ Cardinol & $7.3 \mathrm{ab}$ & $89.2 \mathrm{ab}$ & $102.5 \mathrm{abc}$ \\
\hline RR53117 & $7.2 \mathrm{ab}$ & $87.8 \mathrm{bc}$ & $100.2 \mathrm{bc}$ \\
\hline RR5345 & $7.3 \mathrm{ab}$ & 87.5 bc & $100.2 \mathrm{bc}$ \\
\hline RR5354 & $7.6 \mathrm{ab}$ & $87.7 \mathrm{bc}$ & $99.2 \mathrm{c}$ \\
\hline RR62196 & $6.8 \mathrm{~b}$ & $88.2 \mathrm{abc}$ & $101.0 \mathrm{bc}$ \\
\hline RR63190 & $7.7 \mathrm{ab}$ & $88.3 \mathrm{abc}$ & $100.8 \mathrm{bc}$ \\
\hline RR70288 & $8.0 \mathrm{ab}$ & $87.0 \mathrm{c}$ & $99.2 \mathrm{c}$ \\
\hline
\end{tabular}

${ }^{2}$ Mean separation of rootstocks within column by Ryan-Einot-GabrielWelsh multiple $F$ test, $\alpha=0.05$; means of five observations per rootstock each year. 
(4.3 and 5.0 days for each stage, respectively) than in 1990 (10.7 and 10.9 days for each stage, respectively). No interaction of year with rootstock was detected for any stage.

Yield components. In 1989, trees on 'Okinawa' x 'Cardinal' had higher yields than trees on B81150 (Table 7). Trees on 'Honeyglo' had a later harvest than trees on 'Love11 seedlings, 'Okinawa' x 'Cardinal' or 62325, and trees on RR63190 had an earlier harvest than trees on 62325 (Table 7). The average fruit load was 145 fruit per tree, and the average fruit size was $158 \mathrm{~g}$, regardless of rootstock. Trees on B820171 were more efficient than trees on B81150, 'Lovell' seedlings, RR5354, or RR5345, and trees on 'Okinawa' $x$ 'Cardinal' were more efficient than trees on RR5345 (Table 7). Trees on RR5345 were more vigorous than trees on RR63190, 'Okinawa' x 'Cardinal', 'Nemaguard', 'Lovell' seedlings, C22889, B89298, B820171, or $\mathrm{B} 813121$ and trees on 62325 were more vigorous than trees on $\mathrm{C} 22889$ or B89298 (Table 7).

In 1990, trees on 'Okinawa' $\mathrm{x}$ 'Cardinal' had higher yields than B81150, B813121, B89298, C22889, C25165, 'Honeyglo', 'Love11 cuttings or seedlings, 'Nemaguard', and all the RR series rootstocks (Table 8). Trees on 62325 had higher yields than trees on RR70288, RR5345, and 'Lovell' seedlings. There was no effect of rootstock on harvest date. Trees on 'Okinawa' $\mathrm{x}$ 'Cardinal' carried more fruit than all other rootstocks except 62325, B820171, and B813121 (Table 8), and there was no effect of rootstock on fruit size (mean fruit weight was $158 \mathrm{~g}$ ). Trees on 'Okinawa' $\mathrm{x}$ 'Cardinal' were more efficient than trees on any other rootstock except 62325, B813121, B820171, or B89298 (Table 8). Trees on RR5345 were more vigorous than trees on 'Okinawa' x 'Cardinal', C22889, B89298, B820171, or $\mathrm{B} 813121$ and trees on 62325 were more vigorous than trees on B89298 (Table 8).

Table 7. Mean yield per tree, percentage of the total crop harvested early, production efficiency, and tree vigor for 'Encore' peach in 1989 as affected by rootstock.

\begin{tabular}{|c|c|c|c|c|}
\hline Rootstock & $\begin{array}{c}\text { Mean } \\
\text { yield/tree } \\
(\mathrm{kg})\end{array}$ & $\begin{array}{l}\text { Total crop } \\
\text { harvested } \\
\text { early } \\
(\%)\end{array}$ & $\begin{array}{l}\text { Production } \\
\text { efficiency } \\
\left(\mathrm{kg} \cdot \mathrm{cm}^{-2}\right)\end{array}$ & $\begin{array}{c}\text { Tree } \\
\text { vigor } \\
\left(\mathrm{cm}^{2} \mathrm{TCSA}^{\mathrm{x}}\right)\end{array}$ \\
\hline 62325 & $25.6 \mathrm{ab}^{\mathrm{y}}$ & $79 a$ & $0.387 \mathrm{abc}$ & $62.5 \mathrm{ab}$ \\
\hline B81150 & $14.8 \mathrm{~b}$ & $26 \mathrm{abc}$ & $0.277 \mathrm{bc}$ & $52.7 \mathrm{abc}$ \\
\hline B813121 & $25.4 \mathrm{ab}$ & $46 \mathrm{abc}$ & $0.528 \mathrm{abc}$ & $49.6 \mathrm{bc}$ \\
\hline B820171 & $34.9 \mathrm{ab}$ & $38 \mathrm{abc}$ & $0.721 \mathrm{a}$ & $48.6 \mathrm{bc}$ \\
\hline B89298 & $19.1 \mathrm{ab}$ & $28 \mathrm{abc}$ & $0.414 \mathrm{abc}$ & $44.8 \mathrm{c}$ \\
\hline C22889 & $20.3 \mathrm{ab}$ & $44 \mathrm{abc}$ & $0.470 \mathrm{abc}$ & $44.5 \mathrm{c}$ \\
\hline C25165 & $29.4 \mathrm{ab}$ & $40 \mathrm{abc}$ & $0.589 \mathrm{abc}$ & $50.4 \mathrm{abc}$ \\
\hline Honeyglo & $23.1 \mathrm{ab}$ & $0 \mathrm{c}$ & $0.444 \mathrm{abc}$ & $54.3 \mathrm{abc}$ \\
\hline Lov. cut & $21.4 \mathrm{ab}$ & $44 \mathrm{abc}$ & $0.420 \mathrm{abc}$ & $53.8 \mathrm{abc}$ \\
\hline Lov. sdlg & $16.9 \mathrm{ab}$ & $73 \mathrm{ab}$ & $0.367 \mathrm{bc}$ & $45.7 \mathrm{bc}$ \\
\hline Nemaguard & $26.5 \mathrm{ab}$ & $57 \mathrm{abc}$ & $0.544 \mathrm{abc}$ & $49.5 \mathrm{bc}$ \\
\hline \multicolumn{5}{|l|}{ Okinawa $x$} \\
\hline Cardinal & $35.1 \mathrm{a}$ & $66 \mathrm{ab}$ & $0.696 \mathrm{ab}$ & $49.2 \mathrm{bc}$ \\
\hline RR53117 & $23.3 \mathrm{ab}$ & $64 a b c$ & $0.471 \mathrm{abc}$ & $50.5 \mathrm{abc}$ \\
\hline RR5345 & $15.8 \mathrm{ab}$ & $64 a b c$ & $0.249 \mathrm{c}$ & $63.9 \mathrm{a}$ \\
\hline RR5354 & $22.0 \mathrm{ab}$ & $27 \mathrm{abc}$ & $0.363 \mathrm{bc}$ & $60.8 \mathrm{abc}$ \\
\hline RR62196 & $23.9 \mathrm{ab}$ & $47 \mathrm{abc}$ & $0.481 \mathrm{abc}$ & $50.2 \mathrm{abc}$ \\
\hline RR63190 & $27.9 \mathrm{ab}$ & $16 \mathrm{bc}$ & $0.598 \mathrm{abc}$ & $49.2 \mathrm{bc}$ \\
\hline RR70288 & $23.0 \mathrm{ab}$ & $26 \mathrm{abc}$ & $0.388 \mathrm{abc}$ & $57.3 \mathrm{abc}$ \\
\hline
\end{tabular}

${ }^{2}$ Trunk cross-sectional area.

${ }^{y}$ Mean separation of rootstocks within column by Ryan-Einot-GabrielWelsh multiple $\mathrm{F}$ test, $\mathrm{a}=0.05$; means of at least five observations per rootstock.
Table 8. Mean yield per tree, number of fruit per tree, production efficiency, and tree vigor for 'Encore' peach in 1990 as affected by rootstock.

\begin{tabular}{|c|c|c|c|c|}
\hline Rootstock & $\begin{array}{c}\text { Mean } \\
\text { yield/tree } \\
(\mathrm{kg}) \\
\end{array}$ & $\begin{array}{c}\text { Fruit/tree } \\
\text { (no.) }\end{array}$ & $\begin{array}{l}\text { Production } \\
\text { efficiency } \\
\left(\mathrm{kg} \cdot \mathrm{cm}^{-2}\right)\end{array}$ & $\begin{array}{c}\text { Tree } \\
\text { vigor } \\
\left(\mathrm{cm}^{2} \text { trunk area }\right) \\
\end{array}$ \\
\hline 62325 & $11.8 \mathrm{ab}^{\mathrm{z}}$ & 57 a & $0.143 \mathrm{ab}$ & $80.0 \mathrm{ab}$ \\
\hline B81150 & $2.3 \mathrm{bc}$ & $15 \mathrm{~b}$ & $0.032 \mathrm{~b}$ & $69.8 \mathrm{abc}$ \\
\hline B813121 & $6.4 \mathrm{bc}$ & $34 a b$ & $0.117 \mathrm{ab}$ & $63.0 \mathrm{bc}$ \\
\hline B820171 & $7.3 \mathrm{abc}$ & $37 \mathrm{ab}$ & $0.124 \mathrm{ab}$ & $62.1 \mathrm{bc}$ \\
\hline В89298 & $4.5 \mathrm{bc}$ & $24 \mathrm{~b}$ & $0.081 \mathrm{ab}$ & $56.1 \mathrm{c}$ \\
\hline C22889 & $4.2 \mathrm{bc}$ & $27 \mathrm{~b}$ & $0.077 \mathrm{~b}$ & $58.3 \mathrm{bc}$ \\
\hline C25165 & $4.5 \mathrm{bc}$ & $26 \mathrm{~b}$ & $0.066 \mathrm{~b}$ & $67.1 \mathrm{abc}$ \\
\hline Honeyglo & $3.2 \mathrm{bc}$ & $21 \mathrm{~b}$ & $0.059 \mathrm{~b}$ & $69.8 \mathrm{abc}$ \\
\hline Lov. cut & $3.4 \mathrm{bc}$ & $17 \mathrm{~b}$ & $0.050 \mathrm{~b}$ & $72.1 \mathrm{abc}$ \\
\hline Lov. sdlg & $1.9 \mathrm{c}$ & $11 \mathrm{~b}$ & $0.030 \mathrm{~b}$ & $64.3 \mathrm{abc}$ \\
\hline Nemaguard & $4.4 \mathrm{bc}$ & $19 \mathrm{~b}$ & $0.068 \mathrm{~b}$ & $63.6 \mathrm{abc}$ \\
\hline \multicolumn{5}{|l|}{ Okinawa $x$} \\
\hline Cardinal & $13.8 \mathrm{a}$ & $73 a$ & 0.228 a & $59.6 \mathrm{bc}$ \\
\hline RR53117 & $3.3 \mathrm{bc}$ & $18 \mathrm{~b}$ & $0.053 \mathrm{~b}$ & $65.2 \mathrm{abc}$ \\
\hline RR5345 & $1.3 \mathrm{c}$ & $7 \mathrm{~b}$ & $0.015 \mathrm{~b}$ & $83.2 \mathrm{a}$ \\
\hline RR5354 & $4.3 \mathrm{bc}$ & $27 \mathrm{~b}$ & $0.054 \mathrm{~b}$ & $79.0 \mathrm{abc}$ \\
\hline RR62196 & $5.0 \mathrm{bc}$ & $25 \mathrm{~b}$ & $0.072 \mathrm{~b}$ & $65.9 \mathrm{abc}$ \\
\hline RR63190 & $2.4 \mathrm{bc}$ & $12 b$ & $0.041 \mathrm{~b}$ & $66.3 \mathrm{abc}$ \\
\hline RR70288 & $2.0 \mathrm{c}$ & $11 \mathrm{~b}$ & $0.027 \mathrm{~b}$ & $73.4 \mathrm{abc}$ \\
\hline
\end{tabular}

${ }^{7}$ Mean separation of rootstocks within column by Ryan-Einot-GabrielWelsh multiple $\mathrm{F}$ test, $\mathrm{a}=0.05$; means of at least five observations per rootstock.

\section{Discussion}

Rootstocks clearly influence spring flower bud development in peach, as previously reported (Okie, 1990, Young and Houser, 1980; Young and Olcott-Reid, 1979). Rootstock effects on bloom date within a cultivar are consistent, since no rootstock $\mathrm{x}$ year interactions were detected for any bud development characteristic in any cultivar. This result is particularly significant, given the extremely different spring temperature profiles of the 2 years (Fig. 1 A,B). The absolute date for development to any particular stage may differ from year to year due to differences in GDH accumulation.

Flower bud growth was accelerated in 1990 compared with 1989, likely due to much higher daily maximum temperatures (Fig. 1) that led to more rapid accumulation of GDHs (Fig. 2). Visible bud development in both years began when 3000 to 4000 GDHs had accumulated. Although buds on all rootstocks took longer to pass through the balloon and fully open stages in 1990 than in 1989, buds on most rootstocks reached $75 \%$ in each stage earlier in Spring 1990 than in 1989 (Fig. 2). More accumulation of GDHs earlier in Spring 1990 initiated bud growth. Beginning the last week of Mar. 1990 (Julian date 81), few GDHs were accumulated compared with 1989, resulting in a prolonged period in which buds remained in the balloon stage (Fig. 2). By the 2nd week of Apr. 1990 (Julian date 100), GDH accumulation resumed, and buds proceeded through the fully open stage. The prolonged balloon stage led to a later "full bloom," even though bud growth began earlier in 1990 than in 1989.

Young and Olcott-Reid (1979) hypothesized that rootstocks delay bloom by delaying the resumption of visible bud growth in the spring rather than by altering the rate of bud development. Our data supports this hypothesis. In 'Redhaven' and 'Rio-OsoGem', the time of initiation of bud growth in the spring determined the date of bloom (Tables 1 and 5), since rootstock did 

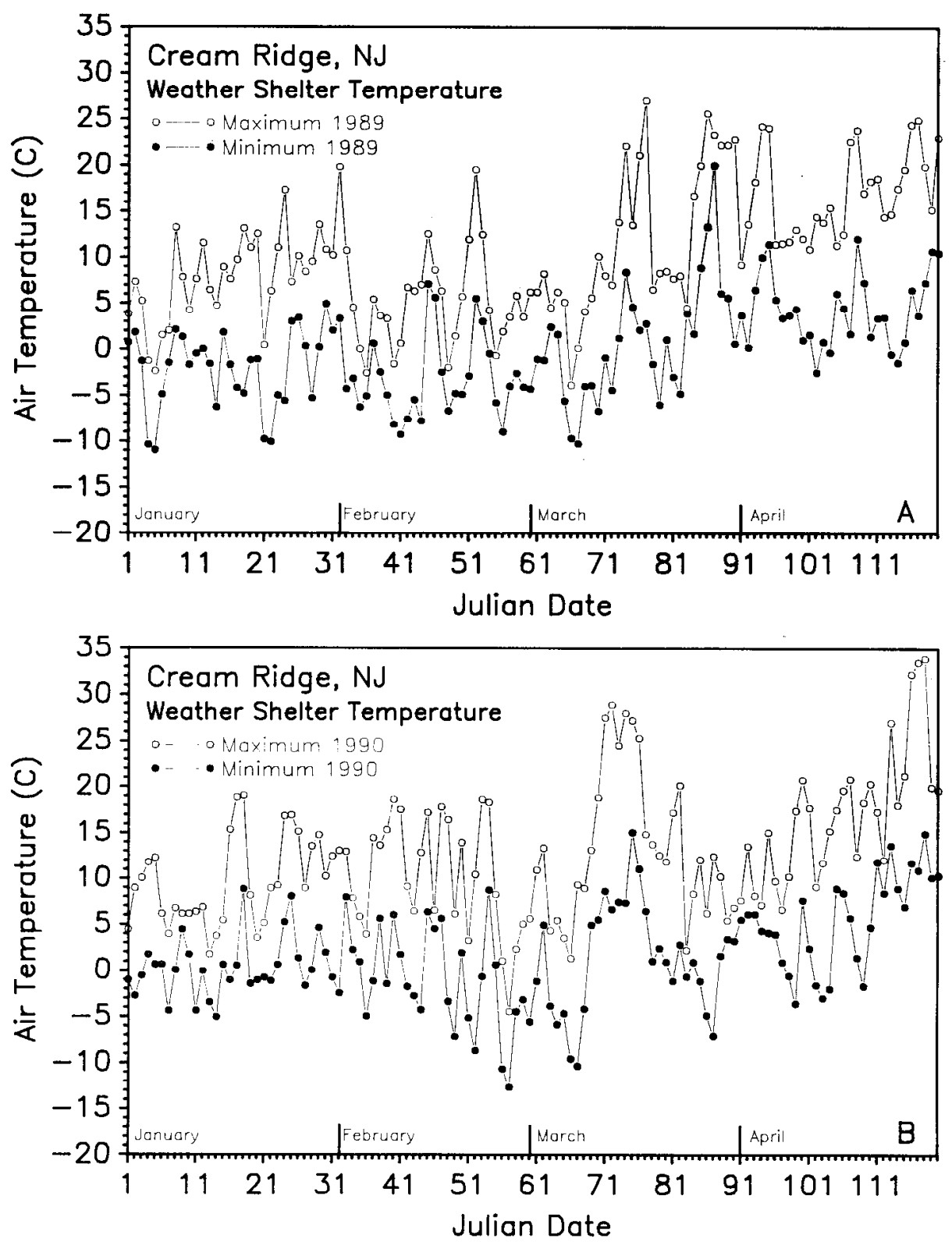

Fig. 1. (A) Maximum and minimum air temperatures at $1.5 \mathrm{~m}$ in a standard weather shelter at Rutgers Fruit Research Center in Cream Ridge, N.J.. for Jan.-Apr. 1989. (B) Maximum and minimum air temperatures at $1.5 \mathrm{~m}$ in a standard weather shelter at Rutgers Fruit Research Center in Cream Ridge, N.J., for Jan.-Apr. 1990.

not influence bud development rates. In 'Encore', later bud development on 62325 and 'Okinawa' $\mathrm{x}$ 'Cardinal' was not associated with slower growth rates. 'Encore' buds on $\mathrm{C} 25165$ had an extended balloon stage, yet the slower bud growth during this stage was not sufficient to result in a later bloom date. In 'Loring', a late bloom on 'Tzim Pee Tao' was largely determined by a slow rate of bud growth during the pink and balloon stages. Thus, the rate and the date of bud growth can influence bloom date. However, for 47 out of 48 scion/cultivar combinations studied, the bloom date was determined primarily by the time of initiation of bud growth in the spring.

A combination of the severity of a frost and the bud stage at the time of a frost determines whether or not a delay in bloom date or decreased bud development rate enhances yield by preventing excessive bud or flower death. A minimum of 11 frosts (six of them late into bloom) occurred during bloom in 1990 compared with five in 1989 (Fig. 1 A and B). In addition, bloom was accelerated in 1990; thus, the late frosts were particularly detrimental. Yield of all cultivars was lower in 1990 than in 1989, regardless of rootstock. Delayed bud development in 'Encore', induced by the rootstocks 'Okinawa' $\mathrm{x}$ 'Cardinal' and 62325 , was sufficient to enhance yield compared with the other rootstocks in 1990 (Table 8). In addition, reduced yield in 'Redhaven' on Damas GF 1869 and GF 655.2 compared with the other rootstocks in 1990 could be associated with early bloom on both rootstocks (Tables 1 and 2,. Yield was not reduced on these two rootstocks compared with the others in 1989 (few frosts). However, early bloom on GF 677 did not decrease yield compared with the other rootstocks in either year (Table 2). In a previous study (Durner, 1990), GF 677 had the lowest bud survival after a midwinter freeze to $-26 \mathrm{C}$, yet had the highest yield of all the rootstocks in the trial. Perhaps the high vigor of 


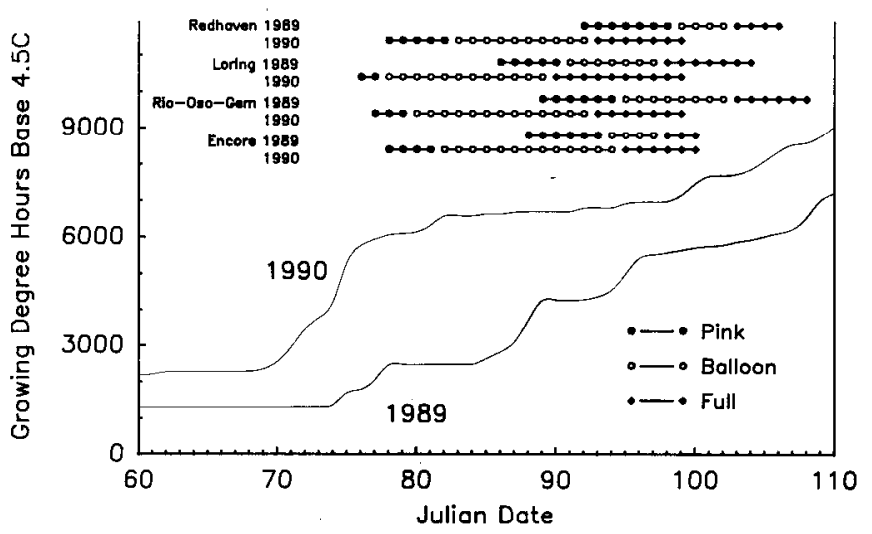

Fig. 2. Growing degree hours (GDH, base 4.5C) at Rutgers Fruit Research Center in Cream Ridge, N.J., for Mar. and Apr. 1989 and 1990.

trees on GF 677 enhances flower bud hardiness against spring freezes and/or frosts, and thus results in higher yields.

Delayed spring bud development (Tables 3 and 5) in 'Loring' or 'Rio-Oso-Gem' did not enhance yield in either year (Table 4). Even though 'Loring' buds on H7338013 were pink and balloon earlier than buds on 'Tzim Pee Tao', yields were similar in both years. Similarly, buds of both 'Loring' and 'Rio-OsoGem' on 'Sinung Chui' were fully open earlier than those of other rootstocks, yet yield was not reduced on these early blooming rootstocks compared with the later-blooming ones in either year. 'Loring' and 'Rio-Oso-Gem' were the earliest-blooming cultivars in this study (Fig. 2); thus, even buds delayed in their development might have been too advanced to withstand the severity of frosts to which they were subjected. An alternative explanation is that rootstock directly affected intrinsic blossom hardiness (i.e., buds on 'Sinung Chui' developed early but were more cold hardy than buds on other rootstocks), even though the rootstocks for 'Loring' and 'Rio-Oso-Gem' in this study did not affect flower bud hardiness (Durner and Rooney, 1988).

Byrne (1986) identified a long bloom period as a major mechanism for avoiding spring frost injury in peach. In our work, a longer bloom period in 1990 (22 to 24 days, Fig. 2) compared with 1989 (13 to 20 days) did not reduce injury to buds from frosts, as estimated by yield. Since prebloom flower bud density was not influenced by rootstock in any cultivar, differences in yield are most likely related to differences in pistil hardiness during and after bloom.

The effect of 'Siberian C' on scion flower bud growth and hardiness has been studied by several researchers. In general, 'Siberian C' delays bloom (Young and Olcott-Reid, 1979; Young and Houser, 1980) and increases flower bud hardiness (Durner, 1990; Layne and Ward, 1978). In our study, 'Siberian C' had the latest date of $75 \%$ fully open flowers (Table 1), although the difference was not statistically significant. It seems likely that rootstocks influence bud development and hardiness by affecting end of rest as well as water and carbohydrate content. 'Siberian C' enhances early scion dormancy in the fall (Layne et al., 1977), increases the scion chilling requirement, delays water inflow into the buds in the spring (Young and Houser, 1980), and slows the depletion of carbohydrate reserves in the spring (Layne and Ward, 1978).

Rootstock influence on the rest period appears to be due to differences in scion chilling requirements imposed by the rootstock rather than to differences in rootstock chilling or heat requirements. Young and Houser (1980) reported that 'Siberian
C' increased the scion chilling requirement by 39 chilling units. Okie (1990) reported a bloom delay of 4 to 10 days in 'Sunprince' budded to the rootstock 'P.I. 101686'. He concluded that the bloom delay was not due to differences in rootstock chilling requirement since 'Sunprince' on 'Flordaking' (chilling requirement of $450 \mathrm{~h}$ at $<7 \mathrm{C}$ ) did not bloom earlier than 'Sunprince' on 'Redglobe' (chilling requirement of $850 \mathrm{~h}$ ). Additionally, Young and Werner (1984) indicated that peach rootstocks do not have a chilling requirement for initiation of root growth. Hammond and Seeley (1978) showed that root temperature did not influence the rate of peach flower bud development in the spring. Thus, bloom is not likely regulated by the heat requirement of rootstocks but rather by the heat requirement of the scion. Differences in the time of bloom on different rootstocks could be related to differences in the base temperature at which roots begin to become more physiologically active in the spring.

Kochba and Samish (1972) reported that 'Nemaguard' and 'Okinawa' root cytokinin levels were lower than in 'Baladi' and 'L 198-12' in a study to determine differences in nematode susceptibility. In our study, 'Nemaguard' and 'Okinawa' x 'Cardinal' both delayed bloom of 'Encore'. This result provides some indirect evidence that decreased root cytokinin levels may be involved, as suggested by Young and Olcott-Reid (1979).

Further evidence that rootstocks directly influence flower growth (specifically, pistil growth) is that rootstocks influence harvest date. In both years, self-rooted trees had an earlier harvest than 'Lovell', even though the total fruit load per tree was not different (Table 2). Fruit growth (and therefore pistil growth) was faster on self-rooted trees than on trees budded to 'Lovell'. Consequently, the rootstock effect on pistil maturation and ripening seems to be direct rather than indirect through a rootstock influence on crop load.

In summary, rootstock may influence both the date and the rate of flower bud development in peach; however, bloom date is determined primarily by the time of initiation of bud growth in the spring. Differences in spring flower bud growth imposed by differences in rootstock do not necessarily result in yield differences. A combination of the severity of the frost and the bud stage at the time of the frost determines whether or not a delay in bloom date or decreased bud development rate enhances yield by preventing excessive bud or flower death. In some cultivars, e.g., 'Redhaven' and 'Encore', delayed bud development resulted in increased yield after spring frosts. In other cases, e.g., 'Rio-Oso-Gem' and 'Loring', no consistent relationship between bloom delay and enhanced yield was detected. However, even 1 or 2 days' delay in blossom development to any stage has the potential to reduce injury from spring frost if the frost occurs when differences in bud development are most pronounced. Rootstock effects on bloom date within a cultivar are consistent over extremely different spring weather conditions; thus, rapid evaluation of rootstocks for their potential ability to delay bloom is possible.

\section{Literature Cited}

Andrews, P.K., E.L. Proebsting, and D.C. Gross. 1983. Differential thermal analysis and freezing injury of deacclimating peach and sweet cherry reproductive organs. J. Amer. Soc. Hort. Sci. 108:755-759.

Bauer, M., C.E. Chaplin, G.W. Schneider, B.J. Barfield, and G.M. White. 1976. Effets of evaporative cooling during dormancy on 'Redhaven' peach wood and fruit bud hardiness. J. Amer. Soc. Hort. Sci. 101:452-454.

Byrne, D.H. 1986. Mechanisms of spring freeze injury avoidance in peach. HortScience 21:1235-1236. 
Durner, E.F. 1990. Rootstock influence on flower bud hardiness and yield of 'Redhaven' peach. HortScience 25:172-173.

Durner, E.F. and T.J. Gianfagna. 1990. Ethephon prolongs dormancy and enhances supercooling in peach flower buds. J. Amer. Soc. Hort. Sci. 116:500-506.

Durner, E.F. and T.J. Gianfagna. 1992. Interactions of ethephon, whitewashing, and dormant oil on pistil growth, hardiness, bloom date and yield in peach. HortScience 27:104-105.

Durner, E.F. and F.X. Rooney. 1988. 'Rio Oso Gem' and 'Loring' peach flower bud and wood hardiness as affected by different rootstocks. Fruit. Var. J. 42:134-138.

Gomez, K.A. and A.A. Gomez. 1984. Statistical procedures for agricultural research. Wiley, New York. 328-332.

Hammond, M.W. and S.D. Seeley. 1978. Spring bud development of Malus and Prunus species in relation to soil temperature. J. Amer. Soc. Hort. Sci. 103:655-657.

Kochba, J. and R.M. Samish. 1972. Level of endogenous cytokinins and auxin in roots of nematode resistant and susceptible peach rootstocks. J. Amer. Soc. Hort. Sci. 97:115-119.

Layne, R.E.C., H.O. Jackson, and F.D. Stroud. 1977. Influence of peach seedling rootstocks on defoliation and cold hardiness of peach cultivars. J. Amer. Soc, Hort, Sci. 102:89-92.

Layne, R.E.C. and G.M. Ward. 1978. Rootstock and seasonal influences on carbohydrate levels and cold hardiness of 'Redhaven' peach. J. Amer. Soc. Hort. Sci. 103:408-413.

Lombard, P.B., N.W. Callan, F.G. Dennis, Jr., N.E. Looney, G.C.
Martin, A.R. Renquist, and E.A. Mielke. 1988. Towards a standardized nomenclature, procedures, values, and units in determing fruit and nut tree yield performance. HortScience 23:813-817.

Okie, W.R. 1990. Ta Tao, P.I. 101686, affects bloom date and tree size of 'Sunprince' peach. Fruit Var. J. 44:87-89.

Quamme, H.A. 1978. Mechanism of supercooling in overwintering peach flower buds. J. Amer. Hort. Sci. 103:57-61.

Richardson, E.A., S.D. Seeley, and D.R. Walker. 1974. A model for estimating the completion of rest for 'Redhaven' and 'Elberta' peach trees. HortScience 1:331-332.

Richardson, E.A., S.D. Seeley, and D.R. Walker. 1975. Pheno-climatography of spring peach bud development. HortScience 10:236237.

Steel, R.G.D. and J.H. Torrie. 1980. Principles and procedures of statistics. A biometrical approach. 2nd ed. McGraw Hill, New York.

Whitten, J.C. 1897. Winter protection of the peach. Mo. Agr, Expt. Sta. Bul. 38.

Young, E. and B. Olcott-Reid. 1979. Siberian C rootstock delays bloom of peach. J. Amer. Soc. Hort. Sci. 104:178-181.

Young, E. and J. Houser. 1980. Influence of Siberian C rootstock on peach bloom delay, water potential, and pollen meiosis. J. Amer. Soc. Hort. Sci. 105:242-245.

Young, E. and D.J. Werner.. 1984. Effects of rootstock and scion chilling during rest on resumption of growth in apple and peach. J. Amer. Soc. Hort. Sci. 109:548-551. 